\title{
Cadmium induced changes in Growth and Biochemical contents of Tomato (Lycopersicon esculentum L.)
}

\author{
Soundari M., T. Vaithiyanathan, P. Sundaramoorthy, \\ Environmental biology Research Laboratory \\ Department of Botany \\ Annamalai University, Annamalai Nagar-608 002 Tamilnadu \\ E-mail address: soundarim33@gmail.com
}

\author{
Keywords: Cadmium, Seed germination, Shoot length, Root length ,Biochemicals, Peroxidase \\ activity.
}

\begin{abstract}
The effects of different concentrations (10,20,30,40 and $50 \mathrm{ppm})$ of cadmium chloride on seed germination, root length, shoot length, fresh weight, photosynthetic pigments, protein content and peroxidase activity in tomato (Lycopersicon esculentum L.). Higher concentration of Cadmium were reported specially at 40 and $50 \mu \mathrm{m}$ reduced germination significantly. Leaf chlorosis, wilting and leaf abscission were observed in plants with cadmium. Protein content and sugar content were reduced in higher concentrations of cadmium. However, lower concentrations of $\mathrm{CdCl}_{2}$ resulted in higher peroxidase activity in roots and shoots of tomato.
\end{abstract}

\section{INTRODUCTION}

Environmental pollution by metals become extensive as mining and industrial activities increased. Heavy metals have been increasing in soil due to sludge, sewage irrigation, utilization of farmyard manures, fertilizer industry and mine residues. It leads to potential risk for human health when these metals get transferred to crops to the human diet. They play an important role in the environment toxic to species above certain concentrations (Ngayila et al., 2008). At high concentrations, a number of heavy metals have been reported to inhibit the growth and the productivity of crops (Liu et al., 2003). Cadmium is an extremely toxic metal commonly found in industrial workplaces is used extensively in electroplating, industrial paints, manufacture of some types of batteries. It is a non-essential heavy metal that does not have any metabolic function in higher plants. Under natural conditions it exists at low concentrations in most soil. It enters the soil with phosphorus fertilizers, sewage sludge and air pollutants. It has a great mobility in the soil when compared with other heavy metals (Varo et al., 1980). The increasing amount of cadmium in the environment affects various physiological and biochemical processes in plants (Sanita di Toppi and Gabberielli, 1999). Cadmium is a non-essential and highly toxic heavy metal, whose concentration in air, soil and waters is progressively increasing due to human activities. The most common symptom of $\mathrm{Cd}$ phytotoxicity is growth reduction in part due to interference of cadmium with mineral nutrition by hampering the uptake and translocation of essential elements such as $\mathrm{Ca}$ and $\mathrm{K}$ (Khan et al., 1983 and Rubio et al., 1994). Since Ca and K are two plant nutrients that have a direct role in cell growth regulation (Claussen et al., 1997; Becker et al., 2002) the elucidation to germinate of $\mathrm{Cd}$ on uptake, accumulation and distribution both elements in plants seems indispensable. The objective of present study is to examine the effect of cadmium on germination, growth, photosynthetic pigments, protein content,sugar content and peroxidise activity of tomato seedling.

\section{MATERIALS AND METHODS}

Tomato seeds (Lycopersicon esculentum L.) were obtained from authorized private agro centre, Cuddalore. The seeds were surface sterilized with $0.1 \%$ Mercury chloride for 10 minutes, and then rinsed extensively with distilled water. Seeds were placed on soil filled plastic pots with different concentrations $(10,20,30,40$ and $50 \mu \mathrm{m})$ of cadmium to germinate in laboratory condition. 
After 7, days the rates of seed germination were determined. For each cadmium chloride concentration about 20 seeds were tested in three separate experiments. The chlorophyll, protein content and peroxidise activity were estimated 15-day-old tomato seedlings.

\section{RESULTS AND DISCUSSION}

Present investigation revealed that germination was inversely proportional to the concentration of $\mathrm{Cd}$. The lower concentration of $\mathrm{Cd}$ showed increased plant height and phytomas. Cadmium affected root more than shoot, leading to a lower tolerant index for root. The phenomenon can be attributed to the fact that roots are the first organs receiving cadmium ions from soil through apoplastic transport,resulting in a higher Cd accumulation (Drazkiewicz et al., 2003). However higher concentration $(50 \mathrm{ppm})$ hampered the plant height and phytomass significantly. These observations are in agreement with those of (Mehindirata et al., 2000 and Ali khan and Siddhu 2006). Cadmium significantly reduced the pigment contents (chlorophyll a,b total chlorophyll and carotenoid) (Table2).

Heavy metals induced changes in chlorophyll contents may be ascribed to the decreased Fe contents in leaves or an impairment of the ability of roots for transport of Fe. These could be a sequence of $\mathrm{Cd}$ induced changes $\mathrm{Mg}$ and Fe contents in leaf. (Battacharyya and Choudhari 1994) reported the inhibition of chlorophyll biosynthesis at protochlorophyllide stage by interference with the enzyme protochlorophyllide reductase. Low concentration of $\mathrm{Cd}(10 \mathrm{ppm})$ did not affect soluble sugar contents but higher concentration induced a significant increase at (50 ppm) which remained nearly unchanged (Table2).

Inhibition in protein content at higher concentration $(50 \mathrm{ppm})$ were observed while lower concentration $(10 \mathrm{ppm})$ was found to elevate the protein contents. Cadmium treatment decreased the protein contents of seeds at higher concentration, which was further confirmed by Steffens (1997), Rolia et al., (2010). Chlorophyll-a content exceeded that of chlorophyll-b in all test plants, which has been proved by other researches (Mobin and Nafees, 2007, Yasemin et al., 2008). Cadmium caused a decline in carotenoid content (Thapar et al., 2008). In this study, the carotenoid content fell as cadmium concentrations increased (Table 2).

Peroxidises which constitute a wide variety of hemecontaining enzyme act in a wide range of normal and stress related physiological processes in plants (Bruce et al., 1993). In Phaseolus vulgaris roots and ascorbate peroxidases and raised lipid peroxidation (Chaoui et al., 1997). Cadmium affected peroxidase activity differently. At low concentrations (10, 20 and 30ppm) the rates of peroxidase activity in both roots and shoots were higher than that $50 \mathrm{ppm} \mathrm{CdCl}_{2}$ (Table 3).

Table 1: Effect of different concentrations of Cadmium on germination studies of tomato (Lycopersicon esculentum).

\begin{tabular}{|c|c|c|c|c|c|}
\hline $\begin{array}{c}\text { Concentrations } \\
\text { of } \mathbf{C d C l}_{\mathbf{2}} \text { (ppm) }\end{array}$ & $\begin{array}{c}\text { Seed } \\
\text { germination } \\
\text { (\%) }\end{array}$ & $\begin{array}{c}\text { Shoot length } \\
\text { (cm/seedling) }\end{array}$ & $\begin{array}{c}\text { Root length } \\
\text { (cm/seedling) }\end{array}$ & $\begin{array}{c}\text { Fresh weight } \\
\text { (g/seedling) }\end{array}$ & $\begin{array}{c}\text { Dry weight } \\
\text { (mg/seedling) }\end{array}$ \\
\hline Control & 100 & $9.5 \pm 0.35$ & $7.8 \pm 0.15$ & $3.80 \pm 0.04$ & $2.99 \pm 0.01$ \\
\hline 10 & 100 & $9.1 \pm 0.30$ & $7.6 \pm 0.36$ & $2.95 \pm 0.08$ & $2.80 \pm 0.1$ \\
\hline 20 & 90 & $8.9 \pm 0.20$ & $6.5 \pm 0.10$ & $2.55 \pm 0.15$ & $2.15 \pm 0.15$ \\
\hline 30 & 70 & $8.5 \pm 0.20$ & $5.5 \pm 0.20$ & $2.15 \pm 0.1$ & $1.95 \pm 0.17$ \\
\hline 40 & 60 & $7.9 \pm 0.30$ & $5.1 \pm 0.20$ & $1.75 \pm 0.05$ & $1.65 \pm 0.12$ \\
\hline 50 & 40 & $7.2 \pm 0.15$ & $4.7 \pm 0.32$ & $1.54 \pm 0.03$ & $1.25 \pm 0.20$ \\
\hline
\end{tabular}


Table 2: Effect of different concentrations of Cadmium photosynthetic pigments of tomato (Lycopersicon esculentum).

\begin{tabular}{|c|c|c|c|c|}
\hline $\begin{array}{c}\text { Concentrations } \\
\text { of } \mathbf{C d C l}_{\mathbf{2}}(\mathbf{p p m})\end{array}$ & $\begin{array}{c}\text { Chlorophyll a } \\
\text { (mg/g F.W) }\end{array}$ & $\begin{array}{c}\text { Chlorophyll b } \\
\text { (mg/g F.W) }\end{array}$ & $\begin{array}{c}\text { Total chlorophyll } \\
\text { (mg/g F.W) }\end{array}$ & $\begin{array}{c}\text { Carotenoid } \\
\text { (mg/g F.W })\end{array}$ \\
\hline Control & $0.59 \pm 0.05$ & $0.45 \pm 0.01$ & $1.04 \pm 0.01$ & $0.25 \pm 0.01$ \\
\hline 10 & $0.56 \pm 0.03$ & $0.41 \pm 0.01$ & $0.99 \pm 0.01$ & $0.22 \pm 0.01$ \\
\hline 20 & $0.45 \pm 0.12$ & $0.38 \pm 0.02$ & $0.83 \pm 0.01$ & $0.20 \pm 0.01$ \\
\hline 30 & $0.35 \pm 0.02$ & $0.29 \pm 0.34$ & $0.64 \pm 0.01$ & $0.16 \pm 0.01$ \\
\hline 40 & $0.31 \pm 0.03$ & $0.25 \pm 0.01$ & $0.56 \pm 0.01$ & $0.13 \pm 0.01$ \\
\hline 50 & $0.21 \pm 0.02$ & $0.10 \pm 0.03$ & $0.54 \pm 0.01$ & $0.11 \pm 0.01$ \\
\hline
\end{tabular}

Table 3: Effect of different concentrations of Cadmium on protein,soluble sugar content and peroxidise activities in tomato (Lycopersicon esculentum).

\begin{tabular}{|c|c|c|c|}
\hline $\begin{array}{c}\text { Concentrations of } \\
\mathbf{C d C l}_{\mathbf{2}} \text { (ppm) }\end{array}$ & Protein & Soluble sugar & Peroxidise \\
\hline Control & $0.43 \pm 0.03$ & $0.35 \pm 0.03$ & $0.07 \pm 0.02$ \\
\hline 10 & $0.39 \pm 0.01$ & $0.29 \pm 0.02$ & $0.35 \pm 0.02$ \\
\hline 20 & $0.35 \pm 0.02$ & $0.21 \pm 0.01$ & $0.33 \pm 0.02$ \\
\hline 30 & $0.29 \pm 0.01$ & $0.19 \pm 0.01$ & $0.29 \pm 0.02$ \\
\hline 40 & $0.25 \pm 0.02$ & $0.17 \pm 0.01$ & $0.06 \pm 0.02$ \\
\hline 50 & $0.21 \pm 0.02$ & $0.14 \pm 0.02$ & $0.05 \pm 0.02$ \\
\hline
\end{tabular}

\section{REFERENCE}

[1] Ngayila, N., M. Botineau, M.Bauda and J.P.Basly. Myriophyllum alterniflorum DC 2008. Effect of low concentrations of copper and cadmium on somatic and photosynthetic endpoints: A chemometric approach. Ecol. Indicat. 9:307-312.

[2] Liu, D.H., W.S.Jiang, and X.Z.Gao. 2003. Effects of cadmium on root growth, cell division and nucleoli in root tip cells of garlic. Boil. Plant 47: 79-83.

[3] Pinto A.P, Mota A.M, De Varennes and A, Pinto FC (2004). Influence of organic matter on the uptake of cadmium, zinc, copper and iron by sorghum plants. Sci. Tot. Environ 326: 239-247.

[4] Varo, P.,O.L. Helm, M. Nuurtamo, S.Saari and P.Koivi-stonen. 1980. Mineral element composition of finish foods. VIII. Potato, vegetables, fruits, berries, nuts, mushrooms. Acta Agricultural Scandinavica, ration and possible Suppl., 22: 89-113.

[5] Sanita di Toppi. L. and R. Gabberielli, 1999. Response to cadmium in higher plants. Environ. Exp. Bot., 41: 105-130

[6] Khan S., and Khan N.N 1983. Influence of lead and cadmium on the growth and nutrient concentration of tomato (Lycopersicon esculentum) and egg-plant (Solanum melongena). Plant and Soil 74, 384.

[7] Rubio M.I., Escrig I., Martinez-Cortina C., Lopez-Benet F.J.,Sanza 1994. Cadmium and nickel accumulation in rice plants. Effects on mineral nut ration and possible interactions of abscisic and gibberellic acids.Plant Growth Regulation 14, 151.

[8] Claussen M., H. Luthen., M.Blatt and M.Bottger,1997. Auxin -induced growth and its linkage to potassium channels. Planta 201,227. 
[9] Becker D., and R.Hedrich. 2002. Channelling auxin action:modulation of ion transport by indole-3-acetic acid. Plant Molecular Biology 49, 349.

[10] Smith, J.H.C. and A. Beniteiz (1955): Modern methods of Plant Analysis. K.Peach and M.V. Iracey Vol. III. Springer Heidelberg.pp.142-192.

[11] Mehindirata, S., T.O Mahmooduz Zafer and M. Iqbal 2000: Cadmium induced changes in growth and structure of root and stem of Solanum melongena L. Phytomorphol., 50, 243251.

[12] Ali khan, M.A. and G. Siddhu 2006: Phytotoxic effect of cadmium (Cd) on physiology of Urd bean (Vigna mungo (L.) Hepper). Ad. Plant Sci., 19, 439-444.

[13] Bhattacharyya, M. and M.A.Choudhari: Effect of Lead and Cadmium on the biochemical changes in the leaves of terrestrial (Vigna) and aquatic (Hydrilla) plants under solution culture. Ind. J.P1.Physiol., 37, 99-103.

[14] Monisha, D. and H.R. Dhingra 2004:Cadmium partitioning and seed quality in two varieties of pea and their hybrid as influenced by rhizospheric cadmium. Ind.J.Plant Physiol., 9, 15-20.

[15] Steffens, J.C,1997. The heavy metal binding peptides of plants. Ann.Rev. Plant Physiol. Plant Mol. Biol,. 41, 553-575.

[16] Rolia, N.M, S.S. Suvarnakhandi, G.S.Mulgund, R.H. Ratageri and T.C. Taranath 2010: Biochemical responses and accumulation of cadmium in Spirodela polyrhiza. J. Environ Biol., 31, 529-532.

[17] Drazkiewicz, M., A. Tukendorf, and T. Baszynski 2003. Age dependent response of maize leaf segments to cadmium treatment: effect on chlorophyll fluorescence and phytochelation accumulation. J.Plant Physiol. 160:247-254.

[18] Mobin, M. and A.K.Naffes. 2007. Photosynthetic activity, pigment composition and antioxidative response of two mustard (Brassica juncea) cultivars differing in photosynthetic capacity subjected to cadmium stress. J. Plant Phyiol. 164: 601-610.

[19] Yasemin ekmekci, Deniz tanyolac and Beycan ayhan 2008. Effect of cadmium on antioxidant enzyme and photosynthetic activities in leaves of two maize cultivars. J.Plat.Physiol.165: 600-611.

[20] Thapar, R.,A.K.Srivastava, P.Bhargava. Y.Mishra, and I.,C. Rai. 2008. Impact of different abiotic stress on growth, photosynthetic electro transport chain, nutrient uptake ansd enzyme activities of Cu-accumulated Anabaena doliolum. J. Plant Physiol.165:306-316.

[21] Bruce, A.S., A.M.Bajar and P.E. Kolattukudy 1993. Abolition of an inducible highly anionic peroxidise activity in transgenic tomato. Plant Physiol., 101:201-208.

[22] Chaoui, A., M.H. Ghorbal and E. EI Ferjani, 1997a. Effects of cadmium-zinc interactions on hydroponically grown bean (Phaseolus vulgaris L.) Plant Sci., 126:21-28. 